\title{
Sporun Kamu Diplomasisi Açısından Türkiye'nin İmajına Etkisi
}

\author{
Sport's Effect on Turkey's Image from the Point of Public Diplomacy
}

\author{
ORIJIINAL ARASTTIRMA/ \\ ORIGINAL RESEARCH \\ Halil Erdem AKOĞLU ${ }^{1^{*}}$ \\ Tonguç Osman MUTLU²
}

\author{
${ }^{1}$ Ankara Üniversitesi, Spor Bilimleri \\ Fakültesi, Ankara. \\ http://orcid.org/0000-0002-0818-7143 \\ ${ }^{2}$ Muğla Sitkı Koçman Üniversitesi, Spor \\ Bilimleri Fakültesi, Muğla. \\ http://orcid.org/0000-0003-1270-6978
}

\begin{abstract}
Öz
İletişim teknolojilerinin hızla gelişmesi ile dünya üzerinde yaşanan her olaya tüm dünya neredeyse anında ve canlı olarak kolayca ulaşabilmektedir. Kamu diplomasi aktörlerinin de günümüz teknolojisine ayak uydurmaları onları devletlerin önemli bir gücü haline getirmektedir. İnsanların en çok ilgi duyduğu ve takip ettiği büyük spor organizasyonlarını kullanarak kamu diplomasisi uygulamalarını yürütmek birçok gelişmiş ve gelişmekte olan ülkenin öncelikleri arasına girmiştir. Sportif başarı, son 20 yıldır uluslararası ilişkiler literatüründe yumuşak güç unsuru olarak yerini almış ve spor, ülkelerin uluslararası alandaki imajlarının oluşumunda önemli bir etken olmaya başlamıştır. Bu bilgiler doğrultusunda bu çalışmanın amacı, sporun kamu diplomasisi aracı olarak Türkiye'nin imajına etkisini incelemektir. Bu kapsamda uluslararası spor organizasyonlarında yer almış spor yöneticileri, uluslararası hakemler, spor yazarlarını ile çeşitli branşlarda milli takımlarda yer almış veya almakta olan sporcuları ve antrenörleri kapsayan 394 kişiye Gök (2016) tarafından geliştirilen İmaj Ölçeği uygulanmıştır. Uygulanan ölçek analiz edilmiş ve sonuçları değerlendirilmiştir. Sonuç olarak araştırmaya katılan kişiler, Türkiye'nin ülke imajı olarak tesisleşme, uluslararası organizasyonları başarıyla düzenleme, spor alanında zengin bir kültürel mirasa sahip olma ifadelerinde daha olumlu görüş bildirirken, spor kültürünün, spor biliminin yeterli düzeyde oluşmadığı ve spor alanında teknolojinin geri kaldığı bir ülke imajının olduğunu belirtmişlerdir.
\end{abstract}

Anahtar Kelimeler: Kamu Diplomasisi, Spor, İmaj, Spor Diplomasisi
Yayın Bilgisi

Gönderi Tarihi: 18.09 .2018

Kabul Tarihi: 21.12.2018

Online Yayın Tarihi: 31.12 .2018

\begin{abstract}
With the rapid development of communication technologies, the world is able to reach almost all worlds almost instantly and live. The fact that the public diplomacy actors keep pace with today's technology makes them an important power of states. Operating public diplomacy by using large sports organizations that people are most interested in and following is one of the priorities of many developed and developing countries. Sportive success has taken its place as an element of soft power in the international relations literature for the last 20 years and sports has become an important factor in the formation of countries' international image. In the light of this information, the aim of this study is to examine the effect of the sport as an instrument of the public diplomacy on the image of the Turkey. In this context, the Image Scale developed by Gök (2016) was applied to 394 people including sports managers, international referees, sports writers and sportsmen and coaches in various sports branches of international sports organizations. The questionnaires were analyzed and the results were evaluated. In conclusion, it appears that while persons participated in the survey express positive opinion about the image of Turkey in the view of sports facilities, the successfully hosting of international sports organizations, the possessive of the rich cultural heritages in sport field; it has been seen as a country image that sport culture and sport sciences have been able to not reach to an adequate level and it is left behind at technology level in sport field.
\end{abstract}

Keywords: Public Diplomacy, Sport, Image, Sport Diplomacy

\footnotetext{
*Bu araştırma Muğla Sıtkı Koçman Üniversitesi Sosyal Bilimler Enstitüsü, Spor Yöneticiliği ABD Yüksek lisans Öğrencisi Halil Erdem AKOĞLU’nun “Sporun Kamu Diplomasisi Açısından Türkiye’nin İmajına Etkisi” başlıklı tezinden üretilmiştir.

* Sorumlu yazar: Halil Erdem Akoğlu, erdemakoglu@ hotmail.com
} 


\section{GİRIŞ}

Küreselleşen dünyada teknolojinin gelişmesi, sosyal medya araçlarının önem kazanması nedeniyle toplumlar arasındaki mesafeler kısalmış, bir anlamda dünya bir köye dönüşmüştür. İnsanların doğru bilgiye kolayca ulaşabilmesiyle birlikte iletişim artık çift yönlü hale gelmiştir. Geleneksel diplomasi kavramı devletten-devlete olmaktan çıkmış devletten-halka veya halktanhalka şeklini almıştır (Kalın, 2010). Bir ülke başka bir ülke üzerinde çıkarlarına uygun politikalar gerçekleştirmek için stratejiler geliştirmektedir. Geleneksel diplomasi kavramı gelişen teknoloji ile birlikte bu noktada yetersiz kalmakta ve yumuşak güç olarak tabir edilen kamu diplomasisi kavramı devletlere yabancı kamuoyunu etkileme ve istenilen politikaları yumuşak güç aracılığıyla gerçekleştirme firsatı sunmaktadır.

Günümüz uluslararası ilişkiler literatüründe yumuşak güç ve kamu diplomasisi kavramları çok sık yer almaya başlamıştır. Joseph Nye’ye göre sert güç “itmek” tir, yumuşak güç ise “çekmek” tir. Yumuşak güç, başkalarını cezbetme, onların kalbini ve zihnini kazanma yeteneğidir. Ekonomik ve siyasi yaptırım gibi somut yöntemler sert güçle ilişkilendirilirken bunun yanı sıra fikirler, değerler, politikaların meşruiyet algısı gibi soyut kavramlar ise yumuşak güç ögeleri olarak nitelendirilmektedir (Nye, 2011). Yumuşak gücün en önemli unsurlarından biri olan kamu diplomasisinin amacı, bir devletin başka bir devletin halkını, aydınlarını ve politikalarını kendi çıkarları doğrultusunda etkilemeye çalışmasıdır (Akçadă̆, 2010).

Kamu diplomasisi kavramı ilk olarak 1965 yılında “Amerika Birleşik Devletleri’nin Tufts Üniversitesi Fletcher Schools of Law and Diplomacy Dekanı Edmund GULLION" tarafindan kullanılmıştır. Gullion’a göre kamu diplomasisi, bir ülkenin dış politikasının oluşturulması ve uygulanması sürecinde politikaların uygulanacağı diğer uluslararası kamuoyunun tutumlarını etki altına almaktır. Kamu diplomasisi, aynı zamanda yabancı toplumların uluslararası algılarını, tutumlarını ve politikalarını etkilemek üzere yürütülen iletişim sanatı olarak da tanımlanmaktadır (Köksoy, 2013).

Bir ülke, sert güç olarak nitelendirilen askeri ve ekonomik yaptırımlar kullanmadan da dünya siyasetinde istediği sonuçları, ülkesinin sahip olduğu değerlere hayranlık duyan, ülkesini örnek alan, ülkenin refah düzeyine ve olanaklarına özenen diğer ülkeleri kendine çekerek ve onları cezbederek de elde edebilir. Yumuşak güç, çekici güçtür ve kaynakları böylesine bir cazibeyi oluşturan değerlerdir (Nye, 2005). 
Kamu diplomasisi, bir ülke imajının ve bilinirliğinin kişisel etkileşim için uygun ortam oluşturabilecek bir güç olduğu varsayımına dayanmaktadır. Uluslararası kongreler, konferanslar, öğrenci değişim programları, kültür-sanat etkinlikleri, sportif faaliyetler ve benzeri kamu diplomasisi uygulama teknik ve yöntemleri ile uzun süreli ilişkilerin oluşturulması, bir taraftan ülkelerin cazibesini artırırken diğer taraftan kalıcı işbirliklerini sağlamakta ve ülke imajına olumlu katkılar sunmaktadır (Özkan, 2014).

Türkiye'nin sahip olduğu kamu diplomasisi uygulama alanlarından biri olan spor, olumlu bir ülke imajının ve ülke markasının oluşturulmasının yanı sıra yabancı kamuoyunun zihninde var olan ülke imajının da iyileştirilmesine yardımcı olabilecek önemli yumuşak güç araçlarındandır. $\mathrm{Bu}$ araçlar kullanılarak oluşturulan ilişkiler sayesinde bir taraftan ülkenin tanınırlığı ve ülke imajı olumlu yönde inşa edilip geliştirilebilirken diğer taraftan olumlu yönde oluşturulan ülke algısından faydalanılarak diğer alanlarda da ilişkiler kurulup işbirlikleri geliştirilebilecektir (Gök, 2016).

Sancar’a (2012) göre uluslararası spor faaliyetleri gelişmiş ve gelişmekte olan ülkeler arasındaki ekonomik ve siyasi farkların giderilmesini sağlamak bakımından ve ilişkileri düzenlemek açısından diplomasi için önemli bir araçtır. Gelişmekte olan ülkeler spor aracılığıyla dünya kamuoyuna kendilerini daha kolay tanıtabilme ve anlatabilme imkanı bulmaktadıllar.

Kotler ve arkadaşlarına (1999) göre; sanayi devrimiyle birlikte ülkeler ve kentler uluslararası alanda imaj sahibi olabilmek için uluslararası sosyal ve kültürel etkinlikler düzenlemeye başlamış ve zaman içerisinde bu etkinlikler içerisinde spor da yerini almıştır. Yenidünya düzeninde artan ülke sayısıyla birlikte, ülkelerin ve kentlerin markalaşması giderek önem kazanmaya başlamıştır. İmaj, markalaşmada önemli ve belirleyici bir rol oynamaktadır. Uluslararası ilişkilerde yeni yeni söz sahibi olmaya başlayan ve bir dönemin gelişmekte olan ülkeleri, marka ülke olma istekleri doğrultusunda küresel marka özelliğindeki spor organizasyonlarının ev sahipliklerine soyunmaktadırlar (Çetin, 2014). 1988 Yaz Olimpiyat Oyunları, 2002 FIFA Dünya Kupası ve 2011 IAFF Dünya Atletizm Şampiyonası'na ev sahipliği yapan Güney Kore, 2014 Kış Olimpiyat Oyunları'na PyeongChang kentiyle aday olmuş ancak PyeongChang kenti adaylığını Rusya'nın Sochi kentine karşı kaybetmiştir. Sovyetler Birliği'nin dağılmasından sonra Rusya, tüm dünyaya modern bir devlet olma yolunda ilerlediğini göstermek için 2014 Kış Olimpiyat Oyunlarını düzenlemiş ayrıca dünyanın en büyük ve önemli spor 
organizasyonlarından sayılan 2018 FIFA Dünya Kupası'na ev sahipliği yapmıştır (Akçadağ, 2013).

Diplomasinin alt dallarından biri olan spor diplomasisi, kamu diplomasisinin araçları arasında yer almaktadır. Spor diplomasisi, bir ülkenin en medeni, en barışçıl ve en fazla kitleye ulaşma imkânı sağlayan diplomasi araçlarındandır ve birçok ülke tarafından faydalanılan önemli kamu diplomasisi aracı olarak kullanılmaktadır (Kurt, 2014).

Spor diplomasisi; sporcular, antrenörler, hakemler, spor yöneticileri aracılığıyla ülkelerini temsil etme ve hatta o ülkenin hükümet yetkilileriyle birlikte hareket eden diplomatik etkinlikleri kapsamaktadır. Spor diplomasisinde amaç yabancı kamuoyu ve spor örgütleri ile bütünleşerek onları kendi ülkeleri hakkında bilgilendirmek aynı zamanda da ülkeleri hakkında olumlu imaj yaratmak ve hükümetin dış politika hedeflerini ifade etmeye yardımcı olmak için hedef kitlelerin algılarını şekillendirmekte kullanılmaktadır (Gök, 2016).

Dolayısıyla spor diplomasisi, bir ülkenin yetiştirdiği sporcudan antrenörüne, hakeminden uluslararası spor örgütlerinde görev alan temsilcilerine kadar tüm unsurlarıyla uluslararası alanda sahneye çıkmakta, aynı zamanda ülkenin cazibesini ve gücünü göstermektedir. Bir ülkenin sporcuları, antrenörleri, hakemleri ve spor yöneticileri, o ülkenin uluslararası alandaki en önemli temsilcileri ve elçileri olarak nitelendirilmektedir.

Yukarıdaki bilgiler 1şığında bu çalışmada, genel olarak amacı yurt içinde ve yurt dışında düzenlenen uluslararası spor organizasyonlarının ülkemize ilişkin olumlu imaj yaratma ya da olumsuz imajın iyileştirilmesinde kültürler arası bir iletişim aracı olarak kamu diplomasisi açısından belirtilen faaliyetlerde kullanılan iletişim stratejilerinin belirlenmesi ve değerlendirilmesi amaçlanmıştır.

\section{YÖNTEM}

\section{Çalışma Grubu}

Araştırmada olasılıklı olmayan örnekleme modeli kullanılmış ve araştırmaya katılan kişilerin, uluslararası spor organizasyonu tecrübesine sahip kişilerden oluşmasına özen gösterilmiştir. Araştırmanın evreni, Ankara'da bulunan Spor Genel Müdürlüğü (622), spor federasyonları (920) ile Türkiye Spor Yazarları Derneği Ankara ve İstanbul şubelerine üye olan 
spor gazetecileri (1554) olmak üzere yaklaşık 3096 kişiden oluşmaktadır. Araştırma evrenini oluşturan 3096 kişiye karş1lık gelen 0,05 örnekleme hatası için örneklem büyüklüğü 346 kişi olarak hesaplanmıştır (Arıkan, 2007).

$\mathrm{Bu}$ araştırmanın örneklem grubunu, Spor Genel Müdürlüğü merkez teşkilatı ve spor federasyonlarında görev yapan spor yöneticileri, milli takım sporcuları ve antrenörleri, uluslararası hakemler ile TSYD Ankara ve İstanbul şubelerine üye olarak kayıtlı spor gazetecileri arasından olasılığa dayalı olmayan örnekleme yöntemi ile uluslararası düzeyde spor organizasyonlarında görev almış olan 93'ü kadın ve 301'i erkek olmak üzere toplam 394 kişi oluşturmaktadır.

\section{Veri Toplama Aracı}

Veri toplama aracı, iki bölümden oluşmaktadır. Birinci bölümde; yapılan alan yazın araştırması sonucu, araştırma sonuçları ile ilgili olabileceği düşünülen 11 değişkene (soruya) yer verilmiştir. Bu sorular bireylerin; cinsiyet, yaş, eğitim düzeyi, meslek, internetten hangi sıklıkla takip ettikleri ve yabancılar tarafından Türkiye'nin hangi kıtada bilindiğine yönelik sorulardır. İkinci bölümde ise sporun kamu diplomasisi aracı olarak Türkiye'nin imajına etkisinin değerlendirilmesine yönelik Gök (2016) tarafından geliştirilmiş olan 21 adet soruyu içeren ve 5 puanlı likert (5-Kesinlikle kat1liyorum, 4-Katıl1yorum, 3-Fikrim Yok, 2-Kat1lmıyorum, 1Kesinlikle Katılmıyorum) tipi imaj ölçeği bulunmaktadır.

$\mathrm{Bu}$ araştırmada sporun kamu diplomasisi aracı olarak Türkiye'nin imajına etkisini değerlendirmek amacıyla Gök (2016) tarafından geliştirilen ve 21 maddeden oluşan "İmaj Ölçeği” nden yararlanılmıştır. Üç alt boyuttan oluşan ölçeğin Ekonomik-Bilim-Teknoloji alt boyutu 8 madde, siyasal-politik alt boyutu 5 madde ve sosyal-kültürel alt boyutu 6 maddeden oluşmaktadır. Kullanılan ölçeğin Cronbach's Alpha testi sonucunda, güvenilirlik kat sayı puanı EkonomikBilim-Teknoloji boyutu için 0,91, Siyasal-Politik boyutu için 0,82 iken, Sosyal-Kültürel boyutu için ise 0,91 olarak çıkmıştır. Alpar'a (2006) göre ölçeğin alfa katsayısı 0,80-1,00 arasında ise ölçek yüksek güvenilir, 0,60-0,80 arasında ise oldukça güvenilir, 0,40-0,60 arasında ise düşük güvenilir ve 0,00-0,40 arasında ise güvenilir değildir. Bu sonuçlar doğrultusunda ölçeğin yüksek güvenilir olduğu söylenebilir. 


\section{Verilerin Analizi}

Araştırma verilerinin çözümlenmesinde SPSS 24 paket programı kullanılmıştır. Araştırmada kullanılan ölçme aracının ve alt boyutlarının güvenilirlik analizleri için alfa katsayıları incelenmiştir. Alt boyutların birbiriyle olan ilişkisini görmek için ise Pearson Korelasyon Analizi kullanılmıştır. Verilerin normallik dağılımlarına Kolmogrov-Smirnov ve Shapiro-Wilk analizleriyle bakılmış ve normal dağılım göstermediği sonucuna varılmıştır. Merkezi limit teoremine göre N sayısı 30'dan fazla olan analizlerde parametrik testler uygulanmış olup bu teoreme uymayan değişkenlerde non-parametrik testler uygulanmıştır.

Merkezi Limit Teoremine göre; ilgili X değişkenine göre yığının bölünümü normal değilse örnek çapı arttıkça örnekleme dağılımı da normale yaklaşır. Yani n'nin artması ile örnekleme bölünümünün normale yaklaşması arasında doğru orantı vardır. Örnek çapının hangi değerleri için örnekleme bölünümünün normale yaklaşacağı yığına ilişkin bölünümün yatıklık derecesine bağlıdır. Aşırı yatık bölünümler için örnek çapının 30 dolayında olması örnek bölünümünün normalliği için yeterli sayılmaktadır (Çil, 2008)

Ölçeğin güvenilirlik analizinden sonra değerlendirmeye alınan katılımcıların kişisel bilgi formuna verdikleri cevaplara ilişkin yüzde ve frekans dağılımları ile aritmetik ortalamaları verilmiştir. Sonrasında imaj ölçeğinde yer alan alt boyutlara ilişkin kişisel bilgi formunda bulunan bağımsız değişkenler arasında iki ortalama arasındaki farkın anlamlılığı testi (independent t-testMann Whitney U), Pearson Korelasyon analizi ve tek yönlü varyans analizi testi (One Way ANOVA-Kruskal Wallis) uygulanmıştır. Tek yönlü varyans analizi testi sonucunda grupların varyansının homojen olduğu durumlarda Post Hoc Tukey testi kullanılmışken homojen olmadığ1 durumlarda ise Games-Howell testinden yararlanılmıştır. 


\section{BULGULAR}

\section{Demografik Bulgular}

Araştırmada elde edilen verilerin demografik dağılımı Tablo 1'deki gibidir.

Tablo 1. Demografik Verilerin Frekans Dağılımı

\begin{tabular}{|c|c|c|}
\hline Cinsiyet & Frekans & Yüzde (\%) \\
\hline Erkek & 301 & 76.4 \\
\hline Kadın & 93 & 23.6 \\
\hline Yaş & Frekans & Yüzde (\%) \\
\hline 20 yaş ve altı & 61 & 15.5 \\
\hline $21-30$ yaş & 151 & 38.3 \\
\hline $31-40$ yaş & 99 & 25.1 \\
\hline $41-50$ yaş & 42 & 10.7 \\
\hline 51 yaş ve üstü & 41 & 10.4 \\
\hline Eğitim Düzeyi & Frekans & Yüzde (\%) \\
\hline Lise & 96 & 24.4 \\
\hline Önlisans & 35 & 8.9 \\
\hline Lisans & 211 & 53.6 \\
\hline Lisansüstü & 52 & 13.2 \\
\hline Meslek & Frekans & Yüzde (\%) \\
\hline Antrenör & 80 & 20.3 \\
\hline Sporcu & 94 & 23.9 \\
\hline Spor Yöneticisi & 97 & 24.6 \\
\hline İletişim-Medya-Basın & 97 & 24.6 \\
\hline Hakem & 26 & 6.6 \\
\hline Uluslararası Organizasyonları Takip Etme Süresi & Frekans & Yüzde (\%) \\
\hline $1-5 \mathrm{y} 1 \mathrm{l}$ & 82 & 20.8 \\
\hline $6-10$ y1l & 64 & 16.2 \\
\hline 11 yıl ve daha fazla & 248 & 62.9 \\
\hline Uluslararası Organizasyonları Takip Etme Süresi & Frekans & Yüzde (\%) \\
\hline Avrupa & 230 & 58.4 \\
\hline Avrasya & 37 & 9.4 \\
\hline Asya & 127 & 32.3 \\
\hline
\end{tabular}

Tablo 1'e göre araştırmaya katılan bireylerin demografik özelliklerine ilişkin dağılımlar incelendiğinde; araştırmaya katılan bireylerin \%76,4'ünün erkek; \%23,6'sının kadın olduğu görülmektedir. 21-30 yaş aralığındaki bireyler \%38,3 ile lisans eğitim düzeyine sahip bireyler ise \%53,6 ile araştırmaya katılanların çoğunluğunu oluşturmaktadır. Meslek gruplarına göre frekanslar incelendiğinde ise; \%24,6'sının spor yöneticisi ve iletişim-medya-basın mensubu, 
\%23,9'unun milli takım sporcusu, 20,3'ünün antrenör ve \%6,6'sının uluslararası hakem olduğu belirlenmiştir. Bireylerin spor organizasyonlarını takip etme durumlarını belirleyici sorulara verilen cevaplara ilişkin dağılımlarda ise katılımcıların \%62,9'u uluslararası spor organizasyonlarını 11 ve daha fazla yıldır takip ettiğini belirtmişlerdir. Araştırmaya katılan bireyler çoğunlukla, uluslararası alanda Türkiye'nin Avrupa kıtasında $(\% 58,4)$ yer aldığını düşünmektedir.

Tablo 2. Türkiye'nin imajına ilişkin Ekonomik-Bilim-Teknoloji (EBT), Siyasal-Politik (SP) ve Sosyal-Kültürel Boyutları arasındaki ilişki

\begin{tabular}{lccc}
\hline & $\begin{array}{c}\text { Ekonomik-Bilim- } \\
\text { Teknoloji (EBT) }\end{array}$ & Siyasal-Politik (SP) & $\begin{array}{c}\text { Sosyal-Külttürel } \\
\text { (SK) }\end{array}$ \\
\hline Ekonomik-Bilim-Teknoloji (EBT) & - & $0.79^{* *}$ & $0.84^{* *}$ \\
\hline Siyasal-Politik (SP) & $0.79^{* *}$ & - & $0.83^{* *}$ \\
\hline Sosyal-Kültürel (SK) & $0.84^{* *}$ & $0.83^{* *}$ & - \\
\hline
\end{tabular}

Tablo 2'ye bakıldığında Ekonomik-Bilim-Teknoloji (EBT), Siyasal-Politik (SP), SosyalKültürel (SK) boyutları arasında pozitif yönde yüksek düzeyde anlamlı ilişki olduğu görülmüştür. Ayrıca güreşe yönelik algı, ilgi ve tutum puanlarının genel düzeyini belirleyebilmek için normal dağılmayan verilerde ortalamaların kıyaslanmasında daha sağlıklı sonuçlar veren medyan değerleri tercih edilmiştir. Bu doğrultuda her üç değişkene ait medyan değerleri hesaplanmış ve Tablo 4'deki bulgular elde edilmiştir.

Tablo 3. Türkiye'nin imajına ilişkin görüşlerde "Cinsiyet" değişkenine göre t-testi analizi sonuçları

\begin{tabular}{|c|c|c|c|c|c|c|c|}
\hline $\begin{array}{c}\text { Alt } \\
\text { Boyutlar }\end{array}$ & Cinsiyet & $\mathbf{N}$ & $\bar{x}$ & $\mathbf{S}$ & $\mathbf{t}$ & SD & $\mathbf{p}$ \\
\hline 氞 & $\begin{array}{l}\text { Kadın } \\
\text { Erkek }\end{array}$ & $\begin{array}{c}93 \\
301\end{array}$ & $\begin{array}{l}3.18 \\
3.33\end{array}$ & $\begin{array}{l}0.87 \\
0.94\end{array}$ & 0.179 & 392 & 0.17 \\
\hline$\hat{\omega}$ & $\begin{array}{l}\text { Kadın } \\
\text { Erkek }\end{array}$ & $\begin{array}{c}93 \\
301\end{array}$ & $\begin{array}{l}3.25 \\
3.61\end{array}$ & $\begin{array}{l}0.88 \\
0.85\end{array}$ & 0.001 & 392 & 0.01 \\
\hline$\sqrt{\mathscr{L}}$ & $\begin{array}{l}\text { Kadın } \\
\text { Erkek }\end{array}$ & $\begin{array}{c}93 \\
301\end{array}$ & $\begin{array}{l}3.04 \\
3.18\end{array}$ & $\begin{array}{l}0.88 \\
1.00\end{array}$ & 0.238 & 392 & 0.23 \\
\hline
\end{tabular}

Tablo 3 incelendiğinde; Siyasal-Politik (SP) boyutta “cinsiyet” değiş̧enine göre istatistiksel olarak anlamlı farklılık olduğu ve bu farkın erkek $\left(\overline{\mathrm{X}}_{\text {erkekort }}=3,61\right)$ katılımcılar lehine olduğu görülmektedir. Ekonomik-Bilim-Teknoloji (EBT) ve Sosyal-Kültürel (SK) boyutlarda ortalamalar arasında farklılık olmasına rağmen bu farkın istatistiksel olarak anlamlı olmadığ tespit edilmiştir $(\mathrm{p}>0.05)$ 
Tablo 4. Türkiye'nin imajına ilişkin görüşlerde "Yaş" değişkenine göre varyans (One-Way Anova) analizi testi sonuçları

\begin{tabular}{|c|c|c|c|c|c|c|c|c|}
\hline $\begin{array}{c}\text { Alt } \\
\text { Boyutlar }\end{array}$ & Yaş & $\mathbf{N}$ & $\bar{x}$ & $\mathbf{S}$ & $\mathbf{F}$ & SD & $\mathbf{P}$ & Fark * \\
\hline \multirow{6}{*}{ 氠 } & *20 yas ve altı & 61 & 3.91 & 0.74 & \multirow{6}{*}{13.910} & \multirow{6}{*}{$4-389$} & \multirow{6}{*}{0.00} & $1 *-2$ \\
\hline & *21-30 yaş & 151 & 3.40 & 0.86 & & & & $1 *-3$ \\
\hline & $31-40$ yas & 99 & 2.99 & 0.91 & & & & $1 *-4$ \\
\hline & 41-50 yaş & 42 & 2.87 & 0.80 & & & & $1 *-5$ \\
\hline & 51 ve üstü & 41 & 3.14 & 1.01 & & & & $2 *-3$ \\
\hline & & & & & & & & $2 *-4$ \\
\hline \multirow{5}{*}{ के } & *20 yaş ve altı & 61 & 4.02 & 0.72 & \multirow{5}{*}{7.683} & \multirow{5}{*}{$4-389$} & \multirow{5}{*}{0.00} & \\
\hline & $21-30$ yaş & 151 & 3.49 & 0.85 & & & & $1 *-2$ \\
\hline & $31-40$ yaş & 99 & 3.27 & 0.91 & & & & $1 *-3$ \\
\hline & $41-50$ yaş & 42 & 3.46 & 0.81 & & & & $1^{*}-4$ \\
\hline & 51 ve üstü & 41 & 3.59 & 0.86 & & & & $1 \%-5$ \\
\hline \multirow{5}{*}{$\frac{4}{2}$} & *20 yaş ve altı & 61 & 3.89 & 0.74 & \multirow{5}{*}{16.416} & \multirow{5}{*}{ 4-389 } & \multirow{5}{*}{0.00} & \\
\hline & $21-30$ yaş & 151 & 3.23 & 0.91 & & & & $1 *-2$ \\
\hline & $31-40$ yas & 99 & 2.83 & 0.93 & & & & $1 *-3$ \\
\hline & $41-50$ yaş & 42 & 2.74 & 0.92 & & & & $1^{*}-4$ \\
\hline & 51 ve üstü & 41 & 2.89 & 1.04 & & & & $\mathbf{1}^{*}-5$ \\
\hline
\end{tabular}

Tablo 4'de yer alan bulgular sonucunda "yaş" değişkenine göre; kamu diplomasisi aracı olarak sporun Ekonomik-Bilim-Teknoloji (EBT), Sosyal-Kültürel (SK) ve Siyasal-Politik (SP) boyutlarında Türkiye'nin imajına ilişkin görüşlerde bazı yaş gruplarında farklılık olduğu ve bu farkın istatistiksel olarak anlamlı olduğu tespit edilmiştir $(\mathrm{p}<0.05)$.

Kamu diplomasisi aracı olarak sporun Ekonomik-Bilim-Teknoloji (EBT) boyutunda farklılığın hangi yaş grubundan kaynakladığını belirlemek üzere (post - hoc) çoklu karşılaştırma testlerinden olan "Games-Howell”" testi uygulanmıştır. Buna göre, 20 yaş altı grubu $(\overline{\mathrm{X}}=3,91)$ ile 21-30 yaş $(\overline{\mathrm{X}}=3,40), 31-40$ yaş $(\overline{\mathrm{X}}=2,99), 41-50$ yaş $(\overline{\mathrm{X}}=2,87)$ ve 51 yaş üstü $(\overline{\mathrm{X}}=3,14)$ gruplar arasında EBT boyutunda istatistiksel olarak anlamlı farklılık olduğu ve bu farklılığın 20 yaş ve altı grubunun lehine olduğu görülmüştür. Bu gruptaki bireylerin EBT boyutunda Türkiye'nin imajına ilişkin daha olumlu cevaplar verdiği gözlemlenmiştir. Ayrıca 21-30 yaş grubu ( $\overline{\mathrm{X}}=3,40)$ ile 31-40 yaş $(\overline{\mathrm{X}}=2,99)$ ve 41-50 ( $\overline{\mathrm{X}}=2,87)$ yaş grubu arasında istatistiksel olarak anlamlı fark olduğu görülmüş ve bu farkın 21-30 yaş grubu lehine olduğu sonucuna varılmıştır.

Ölçeğin; Siyasal-Politik (SP) boyutu bakıldığında ise 20 yaş ve altı yaş grubu ( $\overline{\mathrm{X}}=4,02)$ ile 21-30 yaş $(\overline{\mathrm{X}}=3,49), 31-40$ yaş $(\overline{\mathrm{X}}=3,27), 41,50$ yaş $(\overline{\mathrm{x}}=3,46)$ ve 51 yaş üstü $(\overline{\mathrm{x}}=3,59)$ grupları arasında istatistiksel olarak anlamlı farklılık tespit edilmiştir. Yapılan analiz sonucunda bu farkın ortalama olarak yüksek olan 21 yaş ve altı grubun lehine olduğu görülmektedir. 
Tablo 5. Türkiye'nin imajına ilişkin görüşlerde bireylerin eğitim düzeyine göre varyans (OneWay Anova) analizi testi sonuçları

\begin{tabular}{|c|c|c|c|c|c|c|c|c|}
\hline $\begin{array}{c}\text { Alt } \\
\text { Boyutlar }\end{array}$ & $\begin{array}{l}\text { Öğrenim } \\
\text { Durumu }\end{array}$ & $\mathbf{N}$ & $\bar{x}$ & $\mathbf{S}$ & $\mathbf{F}$ & SD & $\mathbf{P}$ & Fark* \\
\hline \multirow{4}{*}{ 兽 } & Lise & 96 & 3.83 & 0.79 & \multirow{4}{*}{17.030} & \multirow{4}{*}{$3-390$} & \multirow{4}{*}{0.00} & \multirow{4}{*}{$\begin{array}{l}\mathbf{1}^{*}-2 \\
\mathbf{1}_{-3} \\
\mathbf{1}^{*-4}\end{array}$} \\
\hline & Önlisans & 35 & 3.03 & 0.92 & & & & \\
\hline & Lisans & 211 & 3.18 & 0.91 & & & & \\
\hline & Lisansüstü & 52 & 2.96 & 0.81 & & & & \\
\hline \multirow{4}{*}{$\bar{n}$} & Lise & 96 & 3.94 & 0.78 & \multirow{4}{*}{11.323} & \multirow{4}{*}{$3-390$} & \multirow{4}{*}{0.00} & \\
\hline & Önlisans & 35 & 3.30 & 0.90 & & & & $1 * 3$ \\
\hline & Lisans & 211 & 3.44 & 0.86 & & & & $1 *-4$ \\
\hline & Lisansüstü & 52 & 3.23 & 0.81 & & & & \\
\hline \multirow{4}{*}{ 光 } & Lise & 96 & 3.75 & 0.90 & \multirow{4}{*}{19.817} & \multirow{4}{*}{$3-390$} & \multirow{4}{*}{0.00} & \multirow{4}{*}{$\begin{array}{l}\mathbf{1}^{*}-2 \\
\mathbf{1}_{-3} \\
\mathbf{1}^{*}-4\end{array}$} \\
\hline & Önlisans & 35 & 3.00 & 0.88 & & & & \\
\hline & Lisans & 211 & 3.00 & 0.95 & & & & \\
\hline & Lisansüstü & 52 & 2.71 & 0.82 & & & & \\
\hline
\end{tabular}

Tablo 5'e göre araştırmaya katılan bireylerin eğitim düzeylerinde istatistiksel olarak anlamlı fark olduğu sonucuna ulaşılmıştır $(\mathrm{p}<0.05)$. Bu farklılığın tüm boyutlar için lise $\left(\overline{\mathrm{X}}_{\mathrm{EBTlise}}\right.$ Ort. $\left.=3,83-\overline{\mathrm{X}}_{\text {SPliseort. }}=3,94-\overline{\mathrm{X}}_{\text {SKliseort. }}=3,75\right)$ grubu lehine olduğu belirlenmiştir.

Tablo 6. Türkiye'nin imajına ilişkin görüşlerde bireylerin meslek gruplarına göre Kruskal Wallis ve Mann Whitney U testi sonuçları

\begin{tabular}{|c|c|c|c|c|c|c|c|}
\hline $\begin{array}{c}\text { Alt } \\
\text { Boyutlar }\end{array}$ & Meslek Grupları & $\mathbf{N}$ & $\bar{x}$ & SD & $\mathbf{X}^{2}$ & $\mathbf{P}$ & Fark* \\
\hline \multirow{6}{*}{ 氞 } & 1.Antrenör & 80 & 204.64 & \multirow{5}{*}{4} & \multirow{5}{*}{64.908} & \multirow{5}{*}{$\mathbf{0 . 0 0}$} & $1-2 *$ \\
\hline & 2.Sporcu & 94 & 272.95 & & & & $1 *-4$ \\
\hline & 3.Yönetici & 97 & 176.19 & & & & $1 *-5$ \\
\hline & 4.Basın-Medya-İletișim & 97 & 154.28 & & & & $2 *-3$ \\
\hline & 5.Hakem & 26 & 143.37 & & & & $2 *-4$ \\
\hline & & & & \multirow{6}{*}{4} & \multirow{6}{*}{49.709} & \multirow{6}{*}{0.00} & $\frac{2 *-5}{1-2 *}$ \\
\hline \multirow{5}{*}{$\hat{n}$} & 1.Antrenör & 80 & 199.37 & & & & $1-2^{*}$ \\
\hline & 2.Sporcu & 94 & 263.18 & & & & $1^{*}-4$ \\
\hline & 3.Yönetici & 97 & 185.54 & & & & $2^{*}-3$ \\
\hline & 4.Basın-Medya-İletişim & 97 & 152.14 & & & & $2^{*}-4$ \\
\hline & 5.Hakem & 26 & 168.13 & & & & $\begin{array}{l}2^{*}-5 \\
3^{*}-4\end{array}$ \\
\hline \multirow{5}{*}{ 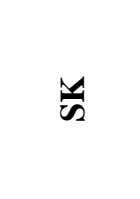 } & 1.Antrenör & 80 & 194.77 & \multirow{5}{*}{4} & \multirow{5}{*}{56.616} & \multirow{5}{*}{0.00} & \multirow{5}{*}{$\begin{array}{l}1-2^{*} \\
\mathbf{2}_{-3} \\
\mathbf{2}_{-4} \\
\mathbf{2}^{*}-5\end{array}$} \\
\hline & 2.Sporcu & 94 & 271.95 & & & & \\
\hline & 3.Yönetici & 97 & 163.73 & & & & \\
\hline & 4.Basın-Medya-İletișim & 97 & 167.88 & & & & \\
\hline & 5.Hakem & 26 & 173.19 & & & & \\
\hline
\end{tabular}

Tablo 6'da meslek gruplarından hakem olanların sayısı merkezi limit teoremine göre 30'dan az olduğu için non-parametrik testlerden Kruskal Wallis uygulanmış ve değişkenler arasındaki farkı bulmak için ise Mann Whitney U testi kullanılmıştır. Türkiye’nin imajına ilişkin 
görüşlerde bireylerin mesleki düzeylerine göre tüm boyutlarda istatistiksel olarak anlamlı fark olduğu sonucuna varılmıştır $(\mathrm{p}<0.05)$. Bu farkın Ekonomik-Bilim-Teknoloji boyutunda tüm meslekler arasından sporcu $(\overline{\mathrm{x}}=272,95)$ olan grup lehine olduğu görülürken; antrenörler $(\overline{\mathrm{x}}=204,64)$ ile basın-medya-iletişim $(\overline{\mathrm{X}}=154,28)$ ve hakem $(\overline{\mathrm{X}}=143,37)$ grupları arasında da “antrenörlerin" lehine istatistiksel olarak anlamlı fark olduğu görülmüştür.

Siyasal-Politik (SP) boyutunda ise yine sporcu $(\overline{\mathrm{X}}=271,18)$ grubu ile tüm meslekler arasında istatistiksel olarak anlamlı fark olduğu görülürken, bu farkın sporcu grubu lehine olduğu tespit edilmiştir. Ayrıca basın-medya-iletişim grubu $(\overline{\mathrm{X}}=152,14)$ ile antrenörler $(\overline{\mathrm{X}}=199,37)$ ve yöneticiler $(\overline{\mathrm{X}}=185,54)$ arasında istatistiksel olarak anlamlı farkın olduğu ve bu farkın antrenörler ve yöneticiler lehine olduğu sonucuna varılmıştır.

Sosyal-Kültürel (SK) boyutunda da diğer boyutlarda olduğu gibi tüm meslek grupları ile sporcu grubu $(\overline{\mathrm{X}}=271,95)$ arasında istatistiksel olarak anlamlı fark tespit edilmiş ve bu farkın tüm gruplarda sporcu grubunun lehine olduğu sonucuna varılmıştır.

Tablo 7. Türkiye'nin imajına ilişkin görüşlerde bireylerin büyük spor organizasyonlarını takip etme sürelerine göre varyans (One-Way Anova) analizi sonuçları

\begin{tabular}{|c|c|c|c|c|c|c|c|c|}
\hline $\begin{array}{c}\text { Alt } \\
\text { Boyutlar }\end{array}$ & Takip Etme Süresi & $\mathbf{N}$ & $\bar{x}$ & $\mathbf{S}$ & $\mathbf{F}$ & SD & $\mathbf{p}$ & Fark* \\
\hline 点 & $\begin{array}{c}\mathbf{5} \text { yil ve daha az } \\
6-10 \text { yıl } \\
\mathbf{1 1} \text { yıl ve daha fazla }\end{array}$ & $\begin{array}{c}82 \\
64 \\
248\end{array}$ & $\begin{array}{l}3.66 \\
3.58 \\
3.10\end{array}$ & $\begin{array}{l}0.84 \\
0.77 \\
0.93\end{array}$ & 16.081 & 393 & 0.00 & *11 yıl ve daha fazla \\
\hline $\bar{n}$ & $\begin{array}{c}\mathbf{5} \text { yil ve daha az } \\
6-10 \text { yıl } \\
11 \text { yıl ve daha fazla }\end{array}$ & $\begin{array}{c}82 \\
64 \\
248\end{array}$ & $\begin{array}{l}3.71 \\
3.73 \\
3.41\end{array}$ & $\begin{array}{l}0.85 \\
0.80 \\
0.88\end{array}$ & 5.916 & 393 & 0.00 & *11 yıl ve daha fazla \\
\hline Us & $\begin{array}{c}5 \text { yıl ve daha az } \\
6-10 \text { yıl } \\
11 \text { yıl ve daha fazla }\end{array}$ & $\begin{array}{c}82 \\
64 \\
248\end{array}$ & $\begin{array}{l}3.58 \\
3.48 \\
2.92\end{array}$ & $\begin{array}{l}0.85 \\
0.84 \\
0.98\end{array}$ & 20.084 & 393 & 0.00 & *11 yıl ve daha fazla \\
\hline
\end{tabular}

Tablo 7'de yer alan bulgular sonucunda kamu diplomasisi aracı olarak spor alanında Ekonomik-Bilim-Teknoloji (EBT), Siyasal-Politik (SP) ve Sosyal-Kültürel (SK) boyutlarında Türkiye'nin imajına ilişkin görüşlerde, uluslararası spor organizasyonlarını takip süresine göre istatistiksel olarak anlamlı fark olduğu sonucuna ulaşılmıştır $(\mathrm{p}<0.05)$. Bu fark, tüm boyutlarda 5 y1l ve daha az takip edenler grubu $\left(\overline{\mathrm{X}}_{\text {EBT5yılalt }}=3,66-\overline{\mathrm{X}}_{\text {SP5ylaltı }}=3,71-\overline{\mathrm{X}}_{\text {SK5ylaltı }}=3,58\right)$ ile 11 y1l ve daha 
fazla $\left(\overline{\mathrm{X}}_{\mathrm{EBT11} \text { ylüstü }}=3,10-\overline{\mathrm{X}}_{\mathrm{SP} 11 \text { yllüstü }}=3,41-\overline{\mathrm{X}}_{\mathrm{SK} 11 \mathrm{y} 1 \mathrm{lüstü}}=2,92\right)$ takip edenler arasindayken 11 y1l ve daha fazla takip edenlerin lehine olduğu sonucuna varılmıştır.

Tablo 8. Türkiye'nin imajına ilişkin görüşlerde, Türkiye'nin yabancılar tarafından daha çok hangi kıtada bilindiğine göre yapılan varyans (One-Way Anova) analizi sonuçları

\begin{tabular}{|c|c|c|c|c|c|c|c|c|}
\hline $\begin{array}{c}\text { Alt } \\
\text { Boyutlar }\end{array}$ & $\begin{array}{l}\text { Türkiye Hangi } \\
\text { Kitada } \\
\text { Bilinmektedir } \\
\end{array}$ & $\mathbf{N}$ & $\bar{x}$ & $\mathbf{S}$ & $\mathbf{F}$ & SD & $\mathbf{P}$ & Fark* \\
\hline 产 & $\begin{array}{l}\text { 1.Avrupa } \\
\text { 2.Avrasya } \\
\text { 3.Asya }\end{array}$ & $\begin{array}{c}230 \\
38 \\
126\end{array}$ & $\begin{array}{l}3.46 \\
2.93 \\
3.09\end{array}$ & $\begin{array}{l}0.89 \\
0.92 \\
0.92\end{array}$ & 10.166 & 393 & 0.00 & $\begin{array}{l}1 *-2 \\
1 *-3\end{array}$ \\
\hline$\hat{n}$ & $\begin{array}{l}\text { 1.Avrupa } \\
\text { 2.Avrasya } \\
\text { 3.Asya }\end{array}$ & $\begin{array}{c}230 \\
38 \\
126\end{array}$ & $\begin{array}{l}3.66 \\
3.25 \\
3.35\end{array}$ & $\begin{array}{l}0.86 \\
0.90 \\
0.85\end{array}$ & 7.472 & 393 & 0.00 & $\begin{array}{l}1^{*}-2 \\
1^{*}-3\end{array}$ \\
\hline$\frac{1}{n}$ & $\begin{array}{l}\text { 1.Avrupa } \\
\text { 2.Avrasya } \\
\text { 3.Asya }\end{array}$ & $\begin{array}{c}230 \\
38 \\
126\end{array}$ & $\begin{array}{l}3.34 \\
2.77 \\
2.90\end{array}$ & $\begin{array}{l}0.95 \\
1.01 \\
0.93\end{array}$ & 11.877 & 393 & 0.00 & $\begin{array}{l}1 *-2 \\
1 *-3\end{array}$ \\
\hline
\end{tabular}

Tablo 8 incelendiğinde; kamu diplomasisi aracı olarak spor alanında Ekonomik-BilimTeknoloji (EBT), Siyasal-Politik (SP) ve Sosyal-Kültürel (SK) boyutlarında Türkiye'nin yabancılar tarafından daha çok hangi kıtada bilindiğine göre bireylerin görüşlerinde istatistiksel olarak anlamlı fark olduğu görülmüştür. $\mathrm{Bu}$ anlamlı farkın tüm boyutlar için Avrupa kıtası $\left(\overline{\mathrm{X}}_{\text {EBTavrupaort }}=3,46-\overline{\mathrm{X}}_{\text {SPavrupaort }}=3,66-\overline{\mathrm{X}}_{\text {SKavrupaort }}=3,34\right)$ lehine olduğu görülmüştür.

\section{TARTIŞMA ve SONUÇ}

Bir ülkenin imajı yalnızca politik aktörler, dış politikalar, bakanlık yaptırım, tanıtım ve politikalarıyla değil, aynı zamanda çağımızın gerekliliği olan sosyal medya araçları ve iletişim ağları kullanılarak da yapılabilmektedir. Özellikle yurt içinde ve yurt dışında gerçekleşen spor organizasyonlarına katılan sporcular ve taraftarlar o zaman diliminde ve mekânda ülkelerini temsil etmekte ve tanıtmaktadır. $\mathrm{Bu}$ uluslararası organizasyonlar, tüm dünyanın gözü önünde gerçekleşmekte ve ülkelerin medya aracılığıyla ülke tanınırlığına ve ülke imajına olumlu katkılar sağlamasına yardımcı olabilmektedir.

Tablo 2'de yer alan araştırma bulgularına göre sporun kamu diplomasisi aracı olarak Türkiye'nin imajına ilişkin görüşler, cinsiyet değişkenine göre Siyasal-Politik (SP) boyutta istatistiksel olarak anlamlı farklılık göstermiş ve bu boyutta erkeklerin kadınlara göre daha olumlu 
görüşlere sahip olduğu anlaşılmaktadır ( $(\mathrm{p}<0,05)$. Erkeklerin Siyasal ve Politik (SP) boyutunda daha olumlu görüşe sahip olmalarının nedeni, kadınlara göre siyasi ve politik meselelerle daha ilgili olmaları ve bu konuları kadınlara göre daha yakından takip etmeleri olarak gösterilebilir.

Erkeği toplumda egemen olarak kabul eden ataerkil bir anlayışa sahip olan Türkiye'ye bakıldığında, bu anlayış kapsamında kadınların spor ve siyasete ilişkin görüşleri erkeklere göre daha olumsuz bir görünüm sergilemektedir. Kadına ve kadınlığa yüklenen roller ve kadınlık algısı, kadını evle ilişkilendiren, bakım işlerinden sorumlu kılan, kadının bedeni üzerinde hak iddia eden, kadına kırılgan, duygusal, mantıksız (irrasyonel) gibi değerleri yakıştıran bir eğilim göstermektedir. Bu değerler ve zihniyet kalıpları bütünüyle kadının tam yurttaşlı̆̆ı ve dolayısıyla karar verme süreçlerine katılımı önünde önemli engeller oluşturmaktadır. Bu nedenle Türkiye'de daha çok kamusal alan erkeğin var olduğu yaşam alanı olarak algılanmaktadır (KONDA, 2011).

Tablo 3 incelendiğinde, sporun kamu diplomasisi aracı olarak Türkiye'nin imajına ilişkin görüşler bireylerin yaş gruplarına göre tüm boyutlarda 20 yaş ve altı grubun lehine fark gösterirken $(p<0,05)$, bu yaş grubunun Türkiye'nin imajına ilişkin ifadelere daha olumlu cevaplar verdiği görülmüştür. Bu yaş grubundaki katılımcılar daha çok sporculuk ve antrenörlük mesleğiyle uğraşan kişilerdir.

Genel olarak orta yaş grubunda nitelendirebileceğimiz 31-40 yaş grubu katılımcılar, tüm boyutlarda Türkiye'nin imajına ilişkin verdikleri ifadelerde diğer yaş gruplarına göre daha olumsuz görüş bildirmiş̧lerdir. Ölçeğin Sosyal-Kültürel (SK) boyutunda yer alan ifadelere verilen cevaplara bakıldığında, katılımcıların yaşları arttıkça verilen cevapların da daha olumsuz olduğu tespit edilmiştir. Gök'ün (2016) yaptığı benzer çalışmaya bakıldığında 20 yaş ve altı grubun, Siyasal-Politik (SP) boyutta yer alan ifadelere daha olumsuz cevaplar verdiği görülürken, yapılan çalışma sonucunda ise 20 yaş ve altı grubun her üç boyutta da diğer yaş gruplarına göre daha olumlu cevaplar verdiği görülmüştür. Algının ve imajın oluşumunu etkileyen önemli unsurlardan birisi, bireyin sosyal, kültürel, demografik özellikleri, geleceğe ilişkin beklentileri, toplumsal konumu ve tecrübeleri ile öğrenilmiş olgulardır. Bireylerin çevresinde gerçekleşen olay ve olguları algılarken ve anlamlandırırken öğrenilmiş olgu ve olayları önceki hayat tecrübeleri ve deneyimlerine göre filtrelerden geçirerek algıladıkları ileri sürülmektedir (Başıüyük, 2014). Başıüyük'ün ifadelerinden yola çıkarak, genç nesil olarak nitelendirebileceğimiz bireylere göre 
hayat tecrübesi edinmiş ve belli bir yaşa erişmiş insanların Türkiye’nin imajı hakkındaki görüşleri, yaşanmışlıkları ile doğru orantılı olarak daha olumsuz yönde artış göstermektedir.

Ne gördüğümüz, nasıl yorumladığımız, neye inandığımız ve nasıl davrandığımız tecrübeye göre farklılık göstermektedir. Bu tecrübeye dayanan imaj algılamanın ise bireylerin görme, duyma, dokunma, koklama ve tat alma şeklindeki duyular ile geliştirilebildiğini ifade etmektedir (aktaran, Şeyhanlığlu, 2014). İnsanlar için imaj ve algı kavramının kişilerin sahip olduğu bilgi ve yaşamışlıkları sonucunda şekillendiği; algılanan imajın ise duyu organları ve hisleri ile zihinsel süzgeçten geçirmek suretiyle yorumladığı söylenebilir. Bununla birlikte zaman içinde insanların yaşadıkları yeni deneyimler ile bir olaya ya da duruma karşı bakış açılarının değişmesi mümkün olabilmektedir.

Tablo 4'e göre sporun kamu diplomasisi aracı olarak Türkiye'nin imajına ilişkin görüşler, bireylerin eğitim durumlarına göre tüm boyutlarda lise mezunu grubun lehinedir. Tüm boyutlarda en olumlu cevapları eğitim düzeyi lise olan katılımcılar verirken lisansüstü eğitim gören katılımcılar ise en olumsuz görüşleri bildirmişlerdir. Bu sonuca göre eğitim düzeyi arttıkça ülke imajı hakkında ki görüşlerin de olumsuz yönde eğilim gösterdiği anlaşılmaktadır. Bireylerin eğitim düzeyleri arttıkça imaja yönelik görüşlerinin daha olumsuz olmasının sebebi, olaylara daha sorgulayıcı ve geniş bakış açılarıyla bakmaları ve değerlendirmeleri olarak gösterilebilir. Eğitim düzeyi lise olan katılımcıların daha olumlu cevaplar vermesinin sebebi olarak ise bu grupta yer alan bireylerin eğitim sisteminin gerektirdiği ve öğrettiği ölçüde ülkeleri hakkında bilgi sahibi olması ve olaylara daha dar bir bakış açısıyla sorgulamadan bakmaları gösterilebilir.

Yakın zamana kadar eğitim, eğitimcilerin büyük çoğunluğunca kabul gören biçimde, bireyin davranışlarında kasıtlı olarak istendik yönde değişiklik oluşturma süreci olarak tanımlanmış ve bireyin davranışını istendik biçimde değiştirmek isteyenin kim olacağı sorusunu gündeme getirmektedir. Bu noktada “isteyen" devlet ve devleti yönetme yetkisini elinde bulunduran egemenlerdir. Bu anlayış eğitim sistemlerinin genel amaçlarından ders içeriklerine kadar yansımıştır (Akın ve Arslan, 2014).

Tablo 4'e göre sporun kamu diplomasisi aracı olarak Türkiye'nin imajına ilişkin görüşler, bireylerin mesleklerine göre tüm boyutlarda sporcu grubunun lehine olarak tespit edilmiştir. EBT boyutunda antrenör grubu ile basın-medya-iletişim ve hakem grubu arasında anlamlı fark çıkmış ve bu farkın antrenör grubunun lehine olduğu sonucuna varılmıştır. 
Bu kapsamda, Türkiye'nin spor alanında uluslararası imajı Ekonomik-Bilim-Teknoloji (EBT), Siyasal-Politik (SP) ve Sosyal-Kültürel (SK) boyutlarında değerlendirildiğinde; sporcu ve antrenör gruplarının daha olumlu görüşler bildirmesinin nedeni olarak, bu grupların diğer meslek gruplarına göre uluslararası spor organizasyonlarda fazla görev almaları ve bu sebeple birçok ülkede bulunarak çok daha fazla insanla bir araya gelmeleri olarak gösterilebilir. Çünkü uluslararası spor organizasyonları nedeniyle antrenör ve sporcu grupları yabancı ülkelerin ekonomisini, teknolojisini, bilimini, siyasi ve politik yapısını aynı zamanda sosyal ve kültürel yönlerini daha çok öğrenme olanağına sahip olabilmekte ve o ülkenin insanlarının Türkiye hakkındaki imajına yönelik düşüncelerini öğrenme imkanı bulabilmektedir.

Bireyler içinde yaşadığı toplumun etkisiyle kişi ya da olayları algılayıp tutumlar oluşturmakta ve bu da toplumsal algıyı meydana getirmektedir. Bireyin aile, akran, arkadaş gibi önemli ötekiler (significant others) ile girdiği ilişki ve etkileşimin algı üzerindeki etkisini grup bağlılıkları ifade etmektedir ve meslek grupları arasında oluşan grup bağlılıkları da algının oluşmasında önemli rol oynamaktadır (Başıbüyük, 2014).

Tablo 5'te sporun uluslararası alanda Türkiye'nin imajına yönelik Ekonomik-BilimTeknoloji (EBT), Siyasal-Politik (SP) ve Sosyal-Kültürel (SK) boyutlarda bireylerin büyük spor organizasyonlarını takip etme sürelerine göre verdikleri cevaplardaki fark 11 yıl ve daha fazla süredir spor organizasyonlarını takip eden katılımcıların lehinedir. Bu sonuçlara göre 11 yıl ve daha fazladır spor organizasyonlarını takip eden bireyler 5 ve daha az ve 6-10 yıl arası takip edenlere göre daha olumsuz ve eleştirel cevap verme eğilimi göstermişlerdir. $\mathrm{Bu}$ araştırma analizleri sonucunda elde edilen veriler ile Gök’ün (2016) yaptığı “Türkiye’nin Gençlik ve Spor Alanındaki Kamu Diplomasisi Etkinliği” adlı çalışmanın spor organizasyonlarını takip etme yılına göre çıkan sonuçlar benzerlik göstermektedir. Her iki araştırmada da "11 ve daha fazla" süredir organizasyonları takip eden bireylerin daha olumsuz görüşler bildirdikleri görülmüştür.

Türkiye sözcüğünün bir yabancıda uyandırdığı çağrışım, görüş ve duygular Türkiye’nin imajını yansıtmaktadır ve bu imaj genel olarak özellikle Avrupa Birliği üyesi ülkelerde olumlu olmaktan uzaktır. İmajın gerçek olmaması durumunda hedeflenen kitlenin zihninde yanlış algılamalar yaratacaktır. Ulusların imajı karmaşık bir süreçle meydana gelir. Süreç, birisinin hayatının ilk yıllarında okul, kitaplar, tiyatro, arkadaşlar gibi deneyimlerle başlar. Ancak kitle 
iletişim araçları, gazete ve dergiler, spor organizasyonları da insan yaşamı süresince kişilerde oluşan imaj1 etkileyen güçlü faktörlerdir (Sancar, 2012).

Kamu diplomasisi açısından sporun ülke imajına bakıldığında kişilerin organizasyonlarda bulunma süreleri arttıkça karşılaştıkları kültürler, görüşler ve insanlar çeşitlenirken kişilerin tecrübeyle ilişkili olarak algılarında da edinilen bilgi ve birikimle orantılı olumlu ya da olumsuz farklılıklar oluşmaktadır.

Tablo 6'da araştırma grubunun Türkiye'nin imajına ilişkin görüşlerinde anlamlı fark tüm boyutlarda Avrupa kıtası lehinedir. Türkiye'nin yabancılar tarafından Avrupa kıtasında bilindiğini söyleyen katılımcılar tüm boyutlarda yer alan ifadelere daha olumlu cevaplar vermişlerdir. Türkiye bu sonuçlara göre değerlendirildiğinde, daha önceki yıllarda yabancı kamuoyu tarafından daha çok Asya kıtasında ve bir Arap ülkesi olarak bilinirken son yıllarda bu algının değiştiği, daha çok Avrupa kıtasında yer aldığı sonucuna varıldığı söylenebilir.

Devletlerin coğrafi özellikleri ve dünya üzerindeki konumlarıyla izledikleri dış politika arasında, doğrudan bir ilişki olduğu bilinmektedir. Diğer faktörler sabit kalmak üzere, ülke coğrafyasının dış politikayı belirlediği savunulmaktadır. Buna göre, ülkenin kara ülkesi ya da okyanuslarla çevrili olması, önemli nehirlere ve deniz ticaret yollarına sahip olması, o ülkenin dış politikasında belirleyici bir etki yaratmaktadır. Dolayısıyla devletler arasındaki rekabette, bu tür coğrafi özellikleri olan bölgelere sahip olmanın sağlayacağı avantaj, önemli rol oynamaktadır. Ayrıca, devletlerin dünya üzerindeki konumu, devletin dış politika gündemini ve önceliklerini belirlemektedir. Bir devletin geniş bir coğrafyaya sahip olması, zengin doğal kaynaklara sahip olmasını etkileyebileceği gibi, iklimsel faktörler de bir ülkenin sahip olduğu kaynakların kullanımını etkileyebilmektedir. Doğal olarak bu değişkenlerde söz konusu olan herhangi bir değişiklik, ülkenin siyasal yapısında ve dış politikadaki etkinliğinde kendisini göstermektedir (Ar1, 2013).

Türkiye, Batı'yla Doğu'nun, Kuzey'le Güney’in buluştuğu bir noktada, Avrasya'nın merkezinde yer alan jeo-stratejik konuma sahip bir ülkedir. Türkiye'nin bulunduğu coğrafi konumdan dolayı küreselleşme sürecinden büyük ölçüde etkilenirken, ayrıca coğrafyasında birçok farklı insan topluluğunun barındırmaktadır. Türkiye, sahip olduğu özel coğrafi konumu ve köklü tarihi nedeniyle kültürler ve medeniyetler arası diyaloğa ev sahipliği yapan bir ülke konumundadır (Bayar, 2008). Jeo-stratejik bir konuma sahip olan Türkiye, yabancı ulus halkları tarafından farklı 
kıtalarda bilinmektedir. Türkiye'nin Avrupa'nın güneydoğusunda bulunması ve Balkan yarımadasının Trakya bölgesine sahip olması, Türkiye'yi Avrupa ülkesi yaparken, Asya kıtasının güneybatı bölgesinde Anadolu yarımadası üzerinde bulunması ve Anadolu ile özdeşleşmesi ülkenin de Asya ülkesi olarak da tanımlanmasına neden olmaktadır (Gök, 2016).

Spor, diplomatik bir araç olarak kamuoyu diplomasisi gibi düşünebilir. Savaş, bir spor olayının sonucu olamaz. UNESCO, yıllar boyunca spor aracılığıyla farklı bölgelere barış ve hoşgörü sağlamaya çalışmaktadır. Spor müsabakaları, iki dost ülke arasındaki iyi ilişkileri bozamaz veya birbirleriyle düşman iki ülke arasına da barış getiremez. Fakat politikacılar, fikirlerini yaymak için sporu önemli bir araç olarak kullanmaktadır (Bainvel, 2005). Spor, ülkeler arası ilişkileri düzeltmek, farklı kültürlerin ve milletlerin bir araya gelmesini sağlamak aynı zamanda da gelişmekte olan toplumların gelişmiş toplum olabilme yolunda önemli diplomatik bir araçtır. Birleşmiş Milletler eski Genel Sekreteri Ban Ki Moon, sporu uluslararası alanda herkesin konuşabileceği bir dil olarak tanımlamış ve kamu diplomasisi kavramında gittikçe önem kazanan sporun, diplomasi ile bir araya getirilerek birçok diş politika hedefine ulaşılabileceğini belirtmiştir (Kurt, 2014).

Dünyanın en büyük spor olayı olarak görülen yaz ve kış olimpiyatları her dört yılda bir düzenlenmekte ve yüz milyonlarca izleyici tarafından aktif ya da pasif olarak takip edilmektedir. Olimpiyat oyunları ev sahibi ülkeye, kültürel zenginliklerini dünyaya tanıtmak, insanlar için iş olanakları sağlamak, turizm gelirlerini arttırmak ve diğer ülkeler ile dostça ilişkiler kurmakta dahil olmak üzere birçok fayda sağlamaktadır. Bu faydaların yanı sıra, Çin’de düzenlenen 2008 Pekin Olimpiyatları'nda Çin Hükümeti gösterişli açılış ve kapanış törenleriyle övgü almasına rağmen, politikalarının insan haklarına aykırı olması ve Tibet halkına saldırması insanların protesto etmesine neden olmuştur. Birçok katılımcı organizasyonu protesto aracı olarak kullanmış ve Çin Hükümeti'ne karşı yabancı kamuoyunda olumsuz imaj yaratmıştır (Yao, 2010). Siyaset, her zaman olimpiyat oyunlarının bir parçası olmuştur. Hatta bazı spor yazarları ve düşünürleri modern olimpiyat oyunlarının siyasi mesajları yaymak için yeniden ortaya çıktığını söylemektedir.

Sonuç olarak, araştırmaya katılanların Türkiye'nin ülke imajı olarak tesisleşme, uluslararası organizasyonları başarıyla düzenleme, spor alanında zengin bir kültürel mirasa sahip olma gibi düşüncelere daha olumlu görüş bildirdikleri anlaş1lırken, daha çok spor kültürünün, spor biliminin yeterli düzeyde oluşmadığı ve spor alanında teknolojinin geri kaldığı imajının olduğu 
görülmektedir. Araştırma grubunun Ekonomik-Bilim-Teknoloji (EBT), Sosyal-Kültürel (SK) ve Siyasal-Politik (SP) boyutlarda yer alan ifadelere genel olarak orta düzeyde katılım gösterdikleri görülmüştür. Sonuçlara göre Türkiye'nin ülke imajının orta düzeyde olduğu görülmektedir.

Bu çalışmadan elde edilen sonuç itibariyle sporun kamu diplomasisi açısından Türkiye'nin imajını olumlu yönde değiştirebilecek önerilerde bulunulmuştur:

- Jeopolitik ve stratejik olarak çok önemli bir konumda bulunan ve bu nedenle tüm dünyanın dikkatini üzerine çeken Türkiye'nin Avrupa ve yabancı kamuoyunda oluşan olumsuz Türkiye imajını, sporun yumuşak gücünü daha etkin ve verimli kullanarak değiştirmesi gerekmektedir.

- 30 Ocak 2010 tarihli ve 27478 sayıli Resmi Gazete'de yayımlanan 2010/3 sayıl1 Başbakanlık Genelgesi ile kurulan Kamu Diplomasisi Koordinatörlüğünün yumuşak güç araçları arasında sporu daha etkin kullanması ve devletin bu kuruma ayırdığı bütçenin arttırılması gerekmektedir.

- Ülkemizde yaşayan insanlarda bir spor kültürü oluş̧urulmalı ve devletimiz bu kapsamda uygulanması mümkün somut politikalar geliştirmelidir.

- Spor bilimlerinde ve bu alanda içinde bulunulan teknoloji takip edebilmek amaciyla ülkemizde bulunan bilim insanlarını spor alanında gelişmiş ülkelere göndererek yeterlilikleri sağlanmalıdır.

- $\mathrm{Bu}$ çalışma uluslararası alanda spor organizasyonlarında görev almış kişilere uygulanmıştır. Bundan sonra bu alanda yapılabilecek çalışmaların yabancı kamuoyu üzerine yapılması daha faydalı olabilecektir.

- Türkiye olarak yabancı kamuoyunda bir marka değeri oluşturulmalıdır. 
Akoğlu, H.E. ve Mutlu, T. O. (2018). Sporun kamu diplomasisi açısından Türkiye'nin imajına etkisi. CBÜ Beden Eğitimi ve Spor Bilimleri Dergisi, 13(2), 277-295.

\section{KAYNAKLAR}

Akçadağ, E. (2010). Dünya'da ve Türkiye'de kamu diplomasisi. [Available online at: http://www.kamudiplomasisi.org/pdf/emineakcadag.pdf], Erişim Tarihi: 15 Temmuz 2017.

Akçadağ, E (2013). Bir kamu diplomasisi örneği olarak Güney Kore.[Available online at:http://www.bilgesam.org/incele/124/-birkamu-diplomasisi-ornegi-olarak-guney-kore/\#.Vb-jvYuRObg], Erişim Tarihi: 28 Ağustos 2017.

Akın, U. ve Arslan, G. (2014). İdeoloji ve Eğitim: Devlet-Eğitim İlişkisine Farklı Bir Bakış. Trakya Üniversitesi Eğitim Fakültesi Dergisi, (4), 81-90.

Alpar, R. (2006). Spor bilimlerinde uygulamalı istatistik. Ankara: Nobel Yayınları.

Arı, T. (2013). Uluslararası ilişkiler kuramları I. Eskişehir: Anadolu Üniversitesi Yayınları.

Arıkan, R. (2016). Araştırma teknikleri ve rapor hazırlama. Ankara: Asil Yayın Dağıtım.

Bainvel, S. (2005). Sport and Politics: A study of the relationship between International Politics and Football. Yayınlanmış yüksek lisans tezi, Linköping Üniversitesi. Iş̧letme ve Mühendislik Bölümü, Linköping.

Bayar, F. (2008). Küreselleşme kavramı ve küreselleşme sürecinde Türkiye. Uluslararası Ekonomik Sorunlar Dergisi (32), 25-34.

Başıüyük, O. (2014). Algı yönetimi. B. Karabulut. (Eds) İçinde, Algı yönetimi ve bilgi savaşlarında sosyal medyanın rolü (ss.3964). İstanbul: Alfa.

Büyüköztürk, Ş., Kılıç Çakmak, E., Akgün, Ö. E., Karadeniz, Ş. ve Demirel, F. (2017). Bilimsel araştırma yöntemleri. Ankara: Pegem.

Çetin, C. (2014). Spor iletişimi "Spor-Tv birlikteliği sattırıyor". Ankara: Nobel.

Çil, B. (2008). İstatistik. Ankara: Detay Yayıncılık.

Gök, Y. (2016). Türkiye'nin gençlik ve spor alanındaki kamu diplomasisi etkinliği. Yayınlanmış doktora tezi, Ankara Üniversitesi, Ankara.

Kalın, İ. (2010). Türk dış politikası ve kamu diplomasisi.[ https://kdk.gov.tr/sag/turk-dis-politikasi-ve-kamu-diplomasisi/20], Erişim Tarihi: 08 Ağustos 2017.

KONDA (2011). Siyasette kadın temsili araştırması. [http://kasaum.ankara.edu.tr/files/2013/11/2011_ 04_KONDA_Siyasette_Kadin_Temsili_Raporu.pdf], Erişim Tarihi: 12 Aralık 2017.

Kotler, P., Armstrong, G., Sounders, J. ve Wony, V. (1999). Principles of marketing: Second European Edition. Prentice-Hall: Europe.

Köksoy, E. (2013). Halkla ilişkiler bağlamında kamu diplomasisi yönetimi Türkiye'nin kamu diplomasisindeki yetkinlik incelemesi. Yayınlanmış doktora tezi, İstanbul Üniversitesi, İstanbul.

Kurt, G. (2014). Türkiye'de spor ve medya. V. Ekin. (Eds) içinde, Spor diplomasisi aracı olarak futbol, Galatasaray profesyonel futbol takımı ve ülke markası ilişkisi üzerine bir araştırma (ss.135-164). İstanbul: Köprü Kitapları.

Nye, J. S. (2005). Dünya siyasetinde başarının yolu yumuşak güç. (Çev.R. İnan Aydın), Ankara: Elips.

Nye, J. S. (2011). The Future of power. New York: Public Affairs.

Özkan, A. (2014). Ülke markası inşasında kamu diplomasisinin stratejik rolü. [http://www.kamudiplomasisi.org/ makaleler/makaleler/138-uelke-markas-nasnda-kamu-diplomasisinin-stratejik-rolue], Erişim Tarihi: 25 Ağustos 2017

Sancar, G. (2012). Kamu diplomasisi ve uluslararası halkla ilişkiler. İstanbul: Beta.

Şeyhanlıoğlu, H. (2014). Algı yönetimi. B. Karabulut. (Eds) içinde, Siyasi partiler ve liderler: Türkiye'den algl ve imaj yönetimi örnekler (ss.331-353). İstanbul: Alfa.

Yao, J. (2010). The effect of hosting the Olympics on national image: An analysis of US newspaper coverage of host countries with reputation problems. Yayınlanmış yüksek lisans tezi, Iowa State University, Iowa. 